Dorota Rak

Instytut Informacii Naukowej i Bibliotekoznawstwa

Uniwersytet Jagielloński

e-mail: dorota.rak@uj.edu.pl

\title{
Programy Teatru Witkacego w perspektywie bibliologicznej
}

DOI: http://dx.doi.org/10.12775/TSB.2015.020

STRESZCZENiE: Niniejszy artykuł jest efektem badań programów teatralnych wydanych w latach 1985-2010 nakładem Teatru im. Stanisława Ignacego Witkiewicza w Zakopanem. Analizie zostały poddane zarówno treść, jak i forma wspomnianych teatraliów. Artykuł prezentuje wybrane przykłady programów (dwa najliczniejsze zespoły: aforystyczno-eseistyczno-graficzne oraz aforystyczno-graficzne), z uwzględnieniem dotychczasowego stanu badań nad dokumentacją teatralną. Istotnym z punktu widzenia tematu był także kontekst bibliotekoznawczy i zagadnienia teoretyczne, które posłużyły jako punkt wyjścia do dalszych rozważań.

SŁowA KLUCzowe: bibliologia, dokumenty życia społecznego, programy, teatralia.

\section{Wprowadzenie}

Treat eatr w Zakopanem założyli w 1985 r. absolwenci Państwowej Wyższej Szkoły Teatralnej w Krakowie. Tak naprawdę działalność rozpoczęła się rok wcześniej, w 1984 r., jedną ze sztuk Witkacego (Pragmatyści), która została zagrana w byłym Zakładzie Wodolecznictwa doktora Andrzeja Chramca. Spektakl stanowił pracę dyplomową studentów kra- 
kowskiej szkoły teatralnej. Szefem grupy od początku jej istnienia jest Andrzej Dziuk, reżyser, który przed rozpoczęciem działalności zakopiańskiego teatru, w latach 1983-1985, współpracował ze sceną Starego Teatru w Krakowie. Zakopiański teatr mieści się przy ulicy Chramcówki 15 (dawny Zakład Wodolecznictwa). Sanatorium, znane kiedyś pod nazwą „Czerwonego Krzyża” było przed laty miejscem spotkań bohemy. Teatr wskrzesza dawną tradycję Zakopanego, które u progu XX w. tętniło życiem artystycznym, do którego przybywali najwybitniejsi artyści okresu Młodej Polski. Zakopiańska scena jest dzisiaj „domem” Witkacego.

W Teatrze Witkacego [dalej: TW] odbyło się do tej pory ponad 100 premier, które układają się w dwa nurty. Z jednej strony w TW obecny jest surrealistyczny humor, ambitny dowcip, widowiska iskrzące się teatralną zabawą, z drugiej strony refleksja nad kondycją człowieka, misteryjne rozważania nad naturą świata ${ }^{1}$. TW jest miejscem, gdzie krzyżują się drogi dobrze wypracowanej praktyki teatralnej, obrośniętej wielowiekową tradycją oraz nowej dramaturgii i poetyki najnowszej inscenizacji. Zakopiańczycy pozostają wierni klasycznym tekstom i „klasycznej" awangardzie, wystawiając ją zawsze stylowo, za każdym razem udowadniając, że swobodnie czują się w świecie teatralnych konwencji. Teoria Czystej Formy stworzona przez Witkiewicza, choć pojmowana niestereotypowo, miała duży wpływ na tworzone przedstawienia i atmosferę teatru (bo Teatr przy Chramcówkach to przecież nie tylko spektakle). TW ze swoimi spektaklami wielokrotnie gościł w Polsce i za granicą. Najczęściej bywał w Gliwicach i Egipcie. Brzmi to paradoksalnie i nieprawdopodobnie, ale podsuwa odpowiedź na pytanie o klimat sceny na Chramcówkach; tak jak Witkacy, Teatr uwielbia skrajności. Był i pomimo upływu czasu jest nadal teatrem artystycznym, takim, o jaki wołał Witkacy, jego duchowy patron.

Lata 1985-2010 stały się okresem ważnym dla TW nie tylko ze względu na aspekt organizacyjny i jego pozycję na mapie teatralnej. Był niezwykle istotny także w kontekście druków do spektakli, jakie wydawał teatr zakopiański. To w tym czasie ukształtował się indywidualny i unikalny charakter dokumentów, którego wpływ jest zauważalny w najaktualniejszych drukach sceny na Chramcówkach.

1 A. Balcerowska-Całka, M. Garbowska, Informator Teatru im. Stanisława I. Witkiewicza, Kraków 2008, s. 5. 
Należy w tym miejscu zaznaczyć, że teatralia stanowią grupę dokumentów, które pełnią w teatrze określone funkcje (informacyjną, promocyjną), są także dokumentami życia społecznego. Zbigniew Żmigrodzki w drugim wydaniu Bibliotekarstwa określa te dokumenty jako informacyjne, normatywne, propagandowe i reklamowe materiały graficzne, które powstają w konsekwencji działań takich grup społecznych, jak instytucje i organizacje, dążących do osiągnięcia określonych celów. Materiały te przybierają najczęściej formę broszur, jednodniówek, afiszy, plakatów, programów, zaproszeń, prospektów, druków reklamowych, ulotek, instrukcji, biuletynów, sprawozdań2. Podstawową ich cechą jest krótkotrwała wartość użytkowa, która aż do końca XIX w. nakazywała nazywać dokumenty życia społecznego drukami ulotnymi. Karol Estreicher starszy w przedmowie do Bibliografii polskiej XIX stulecia nazywał je dojutrkami ${ }^{3}$. Druki te charakteryzowały się stosunkowo małą objętością (jak podaje Encyklopedia wiedzy o książce z 1971 r. - maksymalnie do czterech stron). Współcześnie ich wartość wzrasta o tyle, o ile są wykorzystywane do badań socjologicznych jako dokumenty źródłowe. Dokumenty te są w tym przypadku utrwaloną w sposób materialny ludzką myślą odnoszącą się do aspektów życia społecznego jako szeroko rozumianej aktywności społeczeństwa w zakresie kultury, polityki, gospodarki, sztuki, religii, informacji, nauki, administracji, rozrywki, sportu i wielu innych ${ }^{4}$.

Zainteresowanie dokumentami życia społecznego [dalej: dżs] z naukowego punktu widzenia narodziło się w Polsce dość późno, bo dopiero w okresie powojennym (lata 50.). Przełomem okazał się referat Edwarda Chełstowskiego, wygłoszony podczas konferencji Dokumenty życia społecznego w bibliotece (Wrocław, 1969 r.). W artykule jego autorstwa, opublikowanym w materiałach pokonferencyjnych, odnajdujemy pierwszą definicję dżs-ów $w^{5}$ którą przejęły encyklopedie (m.in. Encyklo-

2 Bibliotekarstwo, pod red. Z. Żmigrodzkiego, Warszawa 1998, s. 187.

${ }^{3}$ K. Estreicher, Bibliografia polska XIX stulecia t. 3, Kraków 1862, s. 518.

${ }^{4}$ A. Firlej-Buzon, Dokumenty życia społecznego w teorii i praktyce bibliotekarskiej w Polsce, Warszawa 2002, s. 25.

${ }^{5}$ E. Chełstowski, Wybrane problemy dokumentacji życia społecznego w bibliotekach, [w:] Dokumenty życia społecznego w bibliotece. Materiały z ogólnokrajowej konferencji zorganizowanej przez Bibliotekę Zakładu Narodowego im. Ossolińskich we Wrocławiu w dniach 2-3 czerwca 1969 roku, pod red. J. Albina, Wrocław-Warszawa-Kraków 1970, s. 19. 
pedia wiedzy o ksiq̨żce oraz Encyklopedia współczesnego bibliotekarstwa polskiego), a także późniejsze opracowania. Wynika z nich, że głównym walorem dżs-ów jest z jednej strony ich funkcja informacyjna, z drugiej dokumentacyjna ${ }^{6}$, stąd dżs-y mają swoje miejsce w bibliotekach i to najczęściej w działach regionalnych. Koniec lat 90. XX w. wniósł do dorobku naukowego szersze opracowania niż tylko encyklopedyczna czy słownikowa definicja. W przywołanym już Bibliotekarstwie pod redakcją Zbigniewa Żmigrodzkiego została uaktualniona definicja dokumentów życia społecznego o dokumenty na nośnikach multimedialnych. Cennych informacji o nich dostarczają także książki Anety Firlej-Buzon Dokumenty życia społecznego w teorii i praktyce bibliotekarskiej w Polsce oraz Druki ulotne i okolicznościowe jako źródła do badań dziejów i kultury Dolnego Śląska lat 1945-1956, a także artykuł Termin „DŻS” oraz jego odpowiedniki w nomenklaturze zagranicznej tejże autorki.

O ile badania nad dżs-ami „mają się dobrze”, o tyle badania nad programami teatralnymi nie cieszą się zbyt dużym zainteresowaniem. Mimo to cenne informacje znajdziemy w artykule Witolda Maja $O$ programach teatralnych ${ }^{7}$. Rozważania dotyczące programów znalazły się także w opracowaniach Ewy Bułhak Poetyka programu teatralnego ${ }^{8}$, a także Emila Orzechowskiego Życie teatralne w świetle towarzyszących mu druków okolicznościowych ${ }^{9}$. Wydawnictwa teatralne są także wspominane w monografiach teatrów, jednak te wzmianki przedstawiają znikomą wartość z punktu widzenia badań nad dokumentacją.

\section{Programy teatralne jako przedmiot badań}

Pierwsze programy teatralne pojawiły się w Polsce w Warszawskich Teatrach Rządowych w 1893 r. ${ }^{10}$ W Wielkiej Brytanii ich historia jest

${ }^{6}$ E. Słomianowska-Kamińska, Dokumenty życia społecznego $w$ bibliotekach akademickich - niektóre dylematy, „Toruńskie Studia Bibliologiczne” 2010, nr 2 (5), s. 147.

7 W. Maj, O programach teatralnych, „Almanach sceny polskiej” 1979, nr 19, s. 14-23.

${ }^{8}$ E. Bułhak, Poetyka programu teatralnego, „Didaskalia” 1996, nr 15, s. 68-69.

9 E. Orzechowski, Życie teatralne w świetle towarzyszących mu druków okolicznościowych, [w:] Druki ulotne i okolicznościowe - wartości i funkcje. Materiały międzynarodowej konferencji naukowej, pod red. K. Migonia, M. Skalskiej-Zlat, A. Żbikowskiej-Migoń, Wrocław 2006, s. 279-296.

10 Z. Raszewski, Bilet do teatru. Szkice, Kraków 1998, s. 18. 
znacznie dłuższa, ponieważ sięga końca XVIII w. ${ }^{11}$ Niektóre ich funkcje pełniły w Polsce prenumerowane afisze, dlatego niektórzy badacze błędnie wskazują, że program wywodzi się właśnie od afisza. 0 ile jednak te drugie miały mniejsze rozmiary od współcześnie znanego afisza i można było zaopatrzyć się w nie na ulicach, o tyle programy sprzedawano wyłącznie w teatrze. Tam, co prawda, również funkcjonowały afisze, jednak były one pozbawione informacji innych niż te dotyczące sztuki. Pod tym względem programy były znacznie obfitsze, zawierały bowiem listę sponsorów. Z czasem ważne stało się to, aby programy mieściły się w torebce, dlatego warszawski drukarz, Franciszek Karpiński, ustalił ich wysokość na $18 \mathrm{~cm}$. Po I wojnie światowej przestrzegano już zasady, aby afisze funkcjonowały na ulicy, zaś programy były dostępne wyłącznie $\mathrm{w}$ teatrze.

Dziś program teatralny jest wydawnictwem, w którym zawiera się takie informacje na temat danego przedstawienia, jak jego tytuł, nazwisko autora sztuki, reżysera, scenografa, kompozytora oraz obsadę ${ }^{12}$. Dane te są zazwyczaj stałe i nie powinny zostać pominięte na etapie projektowania programu i oddawania go do druku.

0 znaczeniu materiałów teatralnych dla bibliologii i bibliotekoznawstwa przekonywał na przełomie lat 60. i 70. XX w. Lucjan Kiełkowski ${ }^{13}$. Znane są związki teatraliów z pracą naukową np. Karola Estreichera, który już w II poł. XIX w. badał m.in. programy teatralne ${ }^{14}$. Trzeba przyznać, że choć programy dzielą los afiszy, biletów, zaproszeń, repertuarów etc. w bibliotekach czy teatralnych archiwach zakładowych, to jednak ze względu na najbardziej rozbudowaną strukturę merytoryczną są szczególnie cennym materiałem z punktu widzenia badań naukowych.

Mimo że bibliologia traktuje programy teatralne po macoszemu, bo na próżno szukać jakichkolwiek opracowań na ich temat, to badania teatrologiczne wypracowały pewien ich podział. Na podstawie analizy tre-

11 M. Rickards, The Encyclopedia of Ephemera. A guide to the fragmentary documents of everyday life for the collector, curator, and historian, ed. by M. Twyman, S. de Beaumont, A. Tanner, London 2001, s. 324.

12 Encyklopedia teatru polskiego, pod red. B. Frankowskiej, Warszawa 2003, s. 335.

${ }^{13}$ L. Kiełkowski, $O$ potrzebie gromadzenia materiałów dotyczq̨cych środowisk artystycznych, [w:] Dokumenty życia społecznego w bibliotece..., s. 55-58.

${ }^{14}$ A. Firlej-Buzon, Druki ulotne i okolicznościowe jako źródła do badań dziejów i kultury Dolnego Śląska lat 1945-1956, Wrocław 2013, s. 56-57. 
ści Witold Maj wyróżnił programy aforystyczne (charakteryzują się znikomą wartością informacyjną; zawierają złote myśli, fragmenty z dzieł literackich czy też sztuki), eseistyczne (zawierają tekst pisany w odniesieniu do danego przedstawienia w postaci artykułu traktującego o dramacie, życiorysu autora, eseju na temat recepcji dzieła), graficzne oraz informacyjne (informacyjno-autorskie). Dawniej funkcjonował jeszcze jeden typ programów, wspomniany przez Maja, ale nieomawiany szerzej, a mianowicie czasopismo ${ }^{15}$. W przypadku TW podział ten uległ znaczącemu rozbudowaniu.

Miał rację Maj, podkreślając, że zacierają się granice między poszczególnymi rodzajami programów ${ }^{16}$. Bardzo trudno znaleźć dzisiaj w czystej postaci program aforystyczny, eseistyczny czy też graficzny, nie mówiąc już o informacyjnym. Ten stan rzeczy podyktowany jest częściowo oczekiwaniami społecznymi, a częściowo spełnianiem artystycznych ambicji osób redagujących program.

Współcześni badacze książki i dziedzin z nią związanych jednogłośnie podkreślają znaczenie dokumentów w procesie komunikowania. Jednak gdyby funkcje charakterystyczne dla książki przenieść na dokument życia społecznego i - co więcej (na potrzeby niniejszych rozważań) - dowolny program teatralny, to jak twierdzi Karol Głombiowski, będzie on „w zależności od swego charakteru decydował i ukierunkowywał «sposób ekspresji» adekwatnie do cech książki”"17. Uzasadnienie tego procesu wydaje się oczywiste - kluczową rolę odgrywa bowiem tekst, którego podstawowym zadaniem jest dystrybucja treści pojmowanej par excellence. Niezależnie od objętości, każdy dokument piśmienniczy istnieje po to, by można go było czytać ${ }^{18}$. Nie ma znaczenia, czy czytelnik poddaje się lekturze encyklopedii, poezji, tekstu naukowego, czy chociażby programu teatralnego. Powyższe odwołania są o tyle istotne, że pozwalają wpisać dokumenty teatru w krąg zainteresowań książką i informacją, a co za tym idzie uzasadniają jeden z sensów opracowywania i wydawania tego typu dokumentów.

15 W. Maj, dz. cyt., s. 16-17.

16 Tamże, s. 17.

17 K. Głombiowski, Ksiq̨żka w procesie komunikacji społecznej, Wrocław 1980, s. 11.

18 J. Wojciechowski, Podstawy pracy z czytelnikiem, Warszawa 1991, s. 5. 
Niewątpliwie programy teatralne stanowią najciekawszą grupę spośród teatraliów. Co więcej, pełnią nie tylko funkcję informacyjną czy też w pewnym stopniu estetyczną, ale są - a raczej powinny być - integralną częścią sztuki. Mimo poglądu, że „dokumentacja nie jest sztuką, a jedynie informacją o sztuce” ${ }^{19}$, pozostaje jednak „absolutnie niezbędna dla całej egzystencji dzieła: jego zrozumienia, przeprowadzania prac konserwatorskich (zarówno konserwacji aktywnej, jak i profilaktycznej), instalacyjnych, aranżacyjnych, wystawienniczych, transportowych i wielu innych"20.

\section{Programy teatralne jako źródło informacii}

Scena na Chramcówkach do 2010 r. wydała ponad sto programów, w następujących odmianach (w niniejszym opracowaniu przyjęto i rozszerzono podział zaproponowany przez W. Maja): aforystyczno-eseistyczno-graficzne, aforystyczno-graficzne, graficzne, eseistyczne, aforystyczne, eseistyczno-graficzne, aforystyczno-informacyjne, eseistyczno-informacyjne. Dominują wśród nich zdecydowanie dwie formy mieszane (ponad 70 programów): aforystyczno-eseistyczno-graficzna (zawierająca tekst aforystyczny, eseistyczny oraz ilustrację) oraz aforystyczno-graficzna (tekst aforystyczny i ilustracja). Jak pisze Ewa Bułhak,

program teatralny składa się z poezji i prozy. Poezja: szereg not, artykułów, wspomnień i wywiadów. Dowiadujemy się z nich wiele o przesłaniu sztuki, zamyśle autora, koncepcji inscenizatora. Proza to jedna lub dwie strony umieszczone zazwyczaj pośrodku, zawierające nazwiska reżysera, tłumacza, aktorów ${ }^{21}$.

Koncepcja ta jest zgoła odmienna od przyjętej w tym opracowaniu, zakładającej, że do sfery aforystycznej (poetyckiej) zalicza się teksty literackie poetyckie i prozatorskie, zaś do eseistycznej teksty krytyczne

19 P. Sztabińska, Dokumentacja, ślad i kreacja artystyczna, „Sztuka i Dokumentacja” 2014, nr 10, s. 76.

${ }^{20}$ M. Jadzińska, Rola dokumentacji w procesie zachowania i konserwacji sztuki wspótczesnej, „Sztuka i Dokumentacja” 2011, nr 4, s. 72.

${ }^{21}$ E. Bułhak, dz. cyt., s. 68. 
oraz życiorysy autorów. E. Bułhak inaczej rozumie poezję i prozę w programie teatralnym. Dla niej poezją jest bowiem to, co u Maja zaliczało się do warstwy aforystycznej i eseistycznej, zaś prozą i $\mathrm{n}$ f o r m a c j a dotycząca chociażby obsady aktorskiej. Takie ujęcie skupia całą energię zawartych w programie słów na ich funkcji poetyckiej, podczas gdy ich głównym zadaniem powinno być przede wszystkim informowanie.

Każdy program, niezależnie od rodzaju, do którego przynależy, pełni funkcje informacyjne. Tak naprawdę każdy program, czy to eseistyczny czy aforystyczny, czy też graficzny, jest jednocześnie programem informacyjnym. Z perspektywy widza istotnymi informacjami są:

a) termin i miejsce przedstawienia,

b) autor sztuki (bywa, że wybór „iść czy nie iść do teatru” uzależniony jest od naszych preferencji dotyczących pisarza),

c) obsada,

d) wykaz sponsorów,

e) dane kontaktowe (aby można było na przykład zarezerwować bilety).

W warstwie tekstowej oprócz informacji wskazanych powyżej funkcjonują także elementy eseistyczne i/lub aforystyczne. I tak na przykład eseistyczny tekst biografii umieszczono w tryptyku do Człapówek... (życiorys Andrzeja Struga) oraz Sztuki (biogram Yasminy Rezy). Teksty krytyczne znalazły się z kolei w programie do Medei oraz Mazepy. Jako komunikat funkcjonujący na pograniczu tekstu aforystycznego i eseistycznego występuje wywiad (Kochanek). Jego „transgraniczność” wynika z jednej strony z faktu, iż może być tekstem informującym o sztuce bezpośrednio, z drugiej zaś w pewnym stopniu tłumaczy jej sens czy też sugeruje sposób odbioru. Jego status zależy więc od nagromadzenia danego rodzaju środków (poetyckich, retorycznych), prowadzących do realizacji funkcji informacyjnej albo poetyckiej i estetycznej.

Niektóre programy ujawniają tendencję do minimalizacji tekstu eseistycznego na rzecz treści aforystycznych. W Kto się boi... jest to zaledwie fragment Filozofii dramatu Józefa Tischnera; Dzień dobry... zaopatrzono już w życiorys Witkacego, a także filozoficzno-historyczno-krytycznoliterackie teksty Anny Micińskiej; w broszurze do Pokusy zaproponowano definicje słownikowe.

Trzeba w tym miejscu zaznaczyć, że funkcję poetycką pełnią w programach mieszanych następujące środki aforystyczne: c y t a t y $\mathrm{z}$ da- 
nej sztuki (Mazepa, Medea), k o l a ż t e k s t o w y, a więc teksty z innych źródeł literackich (Mazepa), d e f i n i c j e przytaczane z różnego rodzaju słowników i encyklopedii, sugerujące sposób odczytania dzieła teatralnego (Pokusa, Mazepa) oraz m o t t o (Kochanek, Człapówki, Mazepa). Różny jest ich status - najwartościowsze są te, w których związki między znaczeniem dosłownym i przenośnym są najsilniejsze. Teksty aforystyczne są różne i albo pochodzą z tekstu sztuki, albo spoza niej jako dopełnienie tego, co wydarzy się na scenie.

W dwóch programach - Katzenjammer z 1990 r. i Wyzwolenie Nowe z 1992 r. - zamieszczono z kolei teksty powiązane z twórczością Witkacego. W przypadku karty do Katzenjammer funkcjonuje datowany na dzień premiery list Leona, którego korzenie sięgają do Matki, dzieła Witkiewicza-Syna, na jakim oparto scenariusz sztuki. W przypadku drugiego programu kompozycja tekstu przypomina tą znaną z dramatu antycznego: obecny jest prolog, epejsodia i exodos, przy czym umiejscowienie oraz odmienne - zarówno wewnątrz danej części, jak i w obrębie całości - czcionki wskazują na różne poziomy interpretacji treści zawartej w poszczególnych epejsodiach. Należy tu zaznaczyć, że w programie tym nie przedrukowano całej sztuki, ale te jej małe fragmenty, które pełnią rolę słów-kluczy. Z kolei program do Wariata i zakonnicy zawiera teksty epickie - listy Witkacego do matki z 7 listopada 1927 r. oraz 2 czerwca $1931 \mathrm{r}$.

K. Głombiowski podkreślał nieodzowną rolę piśmiennictwa w społeczeństwie, a szczególnie w tych jego obszarach, gdzie kształtują się jakiekolwiek relacje komunikacyjne ${ }^{22}$. Uniwersalny model sytuacji komunikacyjnej, w którym Harold D. Lasswell konstytuuje trzy zasadnicze elementy: n a d a w c ę, k o m u n i k a t oraz o d b i o r c ę, w badaniach nad przekazem piśmienniczym nadbudowuje się zupełnie naturalnie i wręcz automatycznie o pojęcie tekstu drukowanego ${ }^{23}$. Proces k o m u n i k o w a n i a, choć nie jest samą l e k t u r ą, pozostaje jej częścią. Etapem kluczowym w tej relacji jest l o k u c j a i p e r l o $\mathrm{k} \mathrm{u} \mathrm{c} \mathrm{j} \mathrm{a}{ }^{24}$. Akt pierwszy oznacza zakomunikowanie, a więc dostarczenie informacji. Akt drugi należy rozumieć jako skutki zakomunikowa-

\footnotetext{
${ }^{22}$ K. Głombiowski, dz. cyt., s. 13.

${ }^{23}$ J. Wojciechowski, Praca z użytkownikiem $w$ bibliotece, Warszawa 2000, s. 11.

24 Tamże, s. 87.
} 
nia (poinformowania), do których można zaliczyć zmniejszenie stopnia niewiedzy, a więc - w konsekwencji - redukcję dyskomfortu z powodu istniejących luk.

Rozważania te są ważne z punktu widzenia niniejszego opracowania, gdyż potencjalny odbiorca programu, w którym występuje i tekst aforystyczny i eseistyczny, staje niejako na rozdrożu. Nie wie bowiem do końca, czy program spełni swoją funkcję zgodnie z przeznaczeniem, a więc poinformuje, czy też zaskoczy swoją estetyką. Takie „ryzyko” jest dostrzegalne niezależnie od typu programu teatralnego i to nie tylko w Teatrze Witkacego, ale w każdym, który tylko decyduje się wydawać program do przedstawienia.

\section{Cechy programów teatralnych}

Autorstwo. Każdy program teatralny tworzy kilka osób: autor projektu graficznego (w przypadku TW jest to także osoba odpowiedzialna za scenografię do danego przedstawienia), redaktor literacki (redaguje informacje, dobiera treści aforystyczne i eseistyczne) oraz dyrektor (akceptuje program). $Z$ analizy podpisów w badanych programach wynika, że najczęściej autorem projektu graficznego była Elżbieta DyakowskaBerbeka. Poza nią za warstwę graficzną odpowiadali: Anna Popek, Katarzyna Gabrat, Marek Mikulski, Elżbieta Wernio, Robert Manowski, Rafał Zawistowski oraz Jerzy Skarżyński.

O ile informacje na temat autora projektu są podane wprost, o tyle identyfikacja redakcji nastręcza spore trudności. Niewiele jest bowiem programów, w których jasno i wyraźnie określony jest redaktor literacki. Braki starano się uzupełnić na podstawie danych dotyczących pracowników działu literackiego w Teatrze Witkacego, zawartych w książce Barbary Świąder pt. W metafizycznej dziurze. Teatr Witkacego w Zakopanem ${ }^{25}$. Ze sporządzonego zestawienia pracowników działu literackiego wynika, że kwestiami literackimi zajmowały się następujące osoby: Iwona Romanówna (01.11.1987-31.07.1994), Barbara Jaskólska (01.10.1987-30.06.1989), Elżbieta Ogrodowska (01.08.1990-31.12.1995), Marze-

${ }^{25}$ B. Świąder, W metafizycznej dziurze. Teatr Witkacego w Zakopanem, Gdańsk 2002, s. 378. 
na Garbowska (od 15.07.1994), Teresa Sabo (01.08.1995-31.08.1998), Agata Balcerowska (od 01.01.2000).

Spośród wymienionych osób redakcją programów zajmowały się przede wszystkim: Romanówna, Ogrodowska, Garbowska, Sabo i Balcerowska. Teksty, które trafiały do programów, dostarczał sam reżyser, a sekretarz literacki łączył je w całość.

Format. Badane programy mieszane wyróżniają się zróżnicowanymi rozwiązaniami pod względem formy. W zbiorach archiwum zakładowego znajdują się liczne pojedyncze karty w formacie A4, luźne fiszki, leporella i broszury.

Programy w formie pojedynczych kart A4 TW wydawał między innymi do premier: Sic et non, If I, Moliere, Puszka Pandory, Pieśń Abelone, Szalej, Tema con Variazioni, Katzenjammer, Wyzwolenia - Nowego, Samotnego wieczoru, Drogi i Ccy-Witkac-Y. Układ formalny i treściowy w tego typu programach, mimo, że odwołuje się do postulatu, aby być jak najprostszym i najbardziej przejrzystym, niesie ogromny ładunekinformacyjny. Jedyną wadą w przypadku kart A4 są ich wymiary - ok. 29,8 x x $21 \mathrm{~cm}$. Problem jest więc niemały, bo - jak pisał Witold Maj - takie programy „nie sposób przechować w damskiej torebce”. Mimo, że nie tylko kobiety są widzami w teatrze, a mężczyźni nie noszą torebek, to jednak ten rodzaj programów jest rzeczywiście nieporęczny. Nie sposób go złożyć ze względu na grubość papieru i konsekwencje, jakie dla jego kompozycji może przynieść sfalcowanie.

Zbliżonymi do kart A4 pod względem prostoty formy są programy fiszkowe, a więc złożone z luźnych kart. Powstawały do takich premier, jak na przykład Autoparodia Witkacego, Tragedia szkocka wg Makbeta Shakespeare'a, Pomroczność jasna Davida Lindsaya-Abaire'a oraz Panopticum wg Juliana Tuwima. Liczba i wymiary fiszek były zróżnicowane. Objętość programów fiszkowych wynosiła od 8 do 21 kart, zaś ich wymiary wahały się od 10 do 20,3 cm (szerokość) oraz od 6,5 do $21 \mathrm{~cm}$ (wysokość).

Formami innego typu są programy rozwijane, a szczególnie leporello (tzw. harmonijka). Teatr Witkacego wydawał je między innymi do premier: OL 12-7 (StEG, WIEN) z 1994 r., Nic (1996), Wariata i zakonnicy (1996), Miguela Manary (1996), Tartuffe (1997), Caliguli (1999), Kurki wodnej (1999), Arsenału zjaw wg sztuki Pirandella (2000), C'est la vie! Henri-Pierre'a Cami (2001), Czarodziejskiej góry (2001), Mazepy (2001), 
Dementia praecox Zakopianiensis (2006), Kołatki (2006) i Kabaretu horyzontalnego (2007). Leporello funkcjonowało obok innych odmian rozwijanych (patrz rys. 1). Programy leporellowe miały zbliżone wymiary, które wynosiły średnio 12 x 21,3 cm.
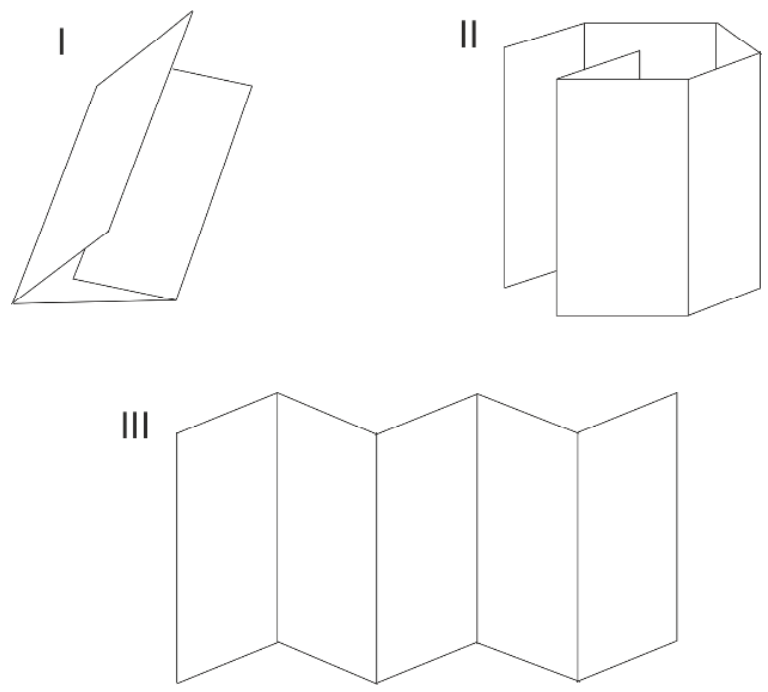

Rysunek 1. Przykłady form w rozwijanych programach teatralnych (I - tryptykowa, II - odwijana, III - leporello).

Źródło: rysunek wykonany przez autorkę.

Oprócz kart, fiszek oraz leporella na uwagę zasługują także programy w postaci broszur. Powstały one do premiery Pokusy (1993), Kto się boi Virginii Woolf (2003), Dzień dobry Państwu - Witkacy (2006). Program do Dżumy przypomina z kolei gazetę codzienną.

Wymiary i kształty broszur są różne - przeważają prostokątne o gabarytach 11,1 x $20 \mathrm{~cm}$ (Dzień dobry...) lub 21 x 13,5 cm (Kto się boi...). Program do Pokusy jest kwadratem o wymiarach 17,1 x 17,1 cm. Z kolei gazeta do Dżumy przejęła rozmiary od tradycyjnej, sfalcowanej gazety, które wynoszą 29,7 x $42 \mathrm{~cm}$. Wielkość broszury (gazety) ma istotny wpływ na rozmieszczenie treści w programie. Zawartość tekstowa składa się z warstwy aforystycznej i eseistycznej, zaś graficzna - ze zdjęć, reprodukcji obrazów oraz rycin. W poszczególnych broszurach elemen- 
ty graficzne występują albo osobno (Kto się boi...), albo razem (Pokusa, Dzień dobry...). Koegzystencja ta widoczna jest także w gazecie do Dżumy. Zróżnicowana jest objętość broszur. Program do Pokusy liczy 24 stron, można go więc uznać za niewielką książeczkę. Z kolei broszury do pozostałych przedstawień liczą odpowiednio: Kto się boi Virginii Woolf? - 12; Dzień dobry Państwu - Witkacy - 8; Dżuma- 8.

Druk. 0 ile na początku istnienia Teatru Witkacego pracownicy sami zajmowali się ręcznym powielaniem egzemplarzy programów, a z czasem zaczęli podejmować się robienia kserokopii na zwykłym papierze kredowym o gramaturze $80 \mathrm{~g} / \mathrm{m}^{3}$, o tyle lata 90 . przyniosły zmiany, które zbliżyły omawianą grupę programów do współczesnych trendów drukarskich i wydawniczych. Stało się to nie tylko przez formę i treść programów, ale także swoistą potrzebę korzystania z darów techniki, a także rosnącą z roku na rok liczbę widzów. Wybór padł na drukarnię "dwóch Janów” - Jana Guzika i Jana Mrożka, mieszczącą się w Nowym Targu. Analizowane programy drukowano metodą offsetu. W praktyce oznaczało to niskie koszty przy większej ilości egzemplarzy, umożliwiało druk dwutonalny lub wielobarwny o dużych rozmiarach. Druk offsetowy pozwalał także na kserograficzne reprodukcje obrazów, które znajdziemy np. w programach do sztuk: Buy some illusions, Sonata Widm Augusta Strindberga czy też Czarownice z Salem Arthura Millera. Programy były w dalszym ciągu drukowane na papierze kredowym, ale o wyższej gramaturze - od 100 do $300 \mathrm{~g} / \mathrm{m}^{3}$.

Ilustracje. Programy wydawane przez Teatr Witkacego zdają się hołdować zasadzie: „lepszy niedosyt niż przesyt”. Prawidłowość ta jest zauważalna w analizowanych teatraliach niezależnie, czy są ozdobione zdjęciem czy reprodukcją obrazu bądź ryciną. Pod względem ilustracji programy TW są bardzo zróżnicowane.

Najmniej „zaawansowaną” grafiką cechuje się tryptyk do Człapówek... ozdobiony jedynie starą fotografią Krupówek z 1926 r. Zdjęcie w formie pocztówki pojawiło się w programach do Kochanka oraz Sztuki. W Medei jej miejsce zajęły zdjęcia ze spektaklu (autorem zdjęć z większości spektakli był Wojciech Plewiński). Inne rozwiązanie zastosowano w Mazepie. Program nie posiada żadnej pocztówki ani fotografii, ale ma wkładkę z matowego, cienkiego, półprzezroczystego papieru.

Zupełnie inny styl reprezentuje broszura do Pokusy. Autorem scenografii do przedstawienia był Jerzy Duda-Gracz. Reprodukcje jego ob- 
razów znalazły się w programie, który jako jedyny pośród broszur jest barwny, bez dominacji jakiegokolwiek koloru, tym bardziej koloru czarnego. Jedynym czarnym elementem jest okładka, na której umieszczono złoty tytuł oraz wytłoczone logo Teatru. Powtórzono je na tylnej okładce, jednakże jako odbicie lustrzane. Chwyt ten ma na celu podkreślić „przezroczystość" wnętrza programu, zamknąć go w ramach określonej kompozycji. Wewnątrz niego - mimo wszystko - znajdują się także ryciny (jest to jeden obrazek, „rozkawałkowany” na pół), mające swoje miejsce na dwóch stronach w samym środku broszury.

W programie do Wyzwolenia-Nowego poważono sięz kolei na umieszczenie reprodukcji malarskiego Autoportretu Stanisława Ignacego Witkiewicza. Katzenjammer zawiera natomiast fotografię Witkacego z okresu niemowlęctwa wraz z matką. W tym programie - jak na imitację prawdziwej pocztówki przystało - obecny jest także znaczek. Co ciekawe, przedstawia on lokomotywę, którą wykorzystano cztery lata później jako graficzny motyw przewodni w programie do OL 12-7 (StEG, WIEN).

Teatr Witkacego uciekał się też do rozwiązań stosunkowo banalnych. Tendencyjne, choć niepozbawione głębszego sensu, było umieszczenie kolorowych szkiców z 1926 r. autorstwa samego Witkacego, które przedstawiały kostiumy do Wyzwolenia-Nowego. W innych swoich programach Teatr Witkacego ujawniał z kolei skłonność do repetycji pod względem pewnych rozwiązań - zapoczątkowana w Katzenjammer konwencja „pocztowa” znalazła także swoje miejsce w 1999 r. w Wariacjach enigmatycznych.

Zupełnie inaczej zaprojektowano program do Na przełęczy Stanisława Witkacego. Swoimi ilustracjami nawiązuje do Nowego Ilustrowanego Przewodnika do Tatr i Pienin Walerego Eljasza. Mapa fizyczna przedstawiająca rzeźbę Tatr z lotu ptaka stanowi tintę (tło), która - oprócz funkcji estetycznej - ma eksponować fragmenty tekstów źródłowych z dzieł literackich tworzących scenariusz sztuki. Front rozłożonego programu zawiera dodatkowo przedruki szkiców rysunkowych z Przewodnika... (po dwa na każdym zewnętrznym skrzydle).

Typografia. W przypadku omawianej grupy programów najbardziej rozpowszechniona jest antykwa linearna bezszeryfowa, tzw. grotesk (szczególnie jego odmiana zwana gillem). Cechą charakterystyczną tego rodzaju czcionek jest jednakowa grubość linii głównych i łączących oraz brak szeryfów, czyli okrągłych lub kreskowych zakończeń liter. Pro- 
gramy do Buy some illusions i Dziury (tylko front rozłożonego programu za wyjątkiem tytułu) zawierają wszystkie trzy możliwe odmiany gillu: cienką, półgrubą i grubą. W komputerowych edytorach tekstu odpowiednikiem gillu jest czcionka Arial (gill cienki). Arial formatowany przy użyciu opcji boldowania (pogrubiania) odzwierciedla odmianę półgrubą, zaś Arial Black, funkcjonujący jako osobna czcionka, odmianę grubą. Odmiana gruba najczęściej spotykana jest w tytule, półgruba przy oznaczeniu poszczególnych odpowiedzialności oraz w informacjach wymagających wyeksponowania, cienka przy pozostałych elementach tekstowych programu (najczęściej w przytoczonych fragmentach z dzieł, na których oparty jest scenariusz sztuki, bądź innych powiązanych z jej treścią).

Ważnym i stałym elementem w programach TW jest charakterystyczna linia z podpisem Witkacego, który tak naprawdę do niego nie należał, ale był - jak większość rzeczy w teatrze - dziełem przypadku podczas pracy plastyka.

\section{Podsumowanie}

TW jest zależny od schematów konstrukcyjnych teatraliów, funkcjonujących na mocy teatrologicznych konwencji, co oznacza, że mimo czynników, które każą zindywidualizować formy wydawnictw i ich treści, nie wykracza on poza przyjęte normy.

Od początków XXI w. zauważalna staje się także tendencja do ograniczania zawartości tekstowej na rzecz grafiki. Szczególnie widoczne staje się to w programach ostatnich lat, gdzie poza tekstami aforystycznymi funkcjonują ograniczone teksty innego typu bądź nie funkcjonują wcale. Wzrasta znaczenie warstwy graficznej, która subtelnie dopełnia przekaz tekstowy i przybliża mniej lub bardziej sens widowiska teatralnego.

Hipoteza zakładająca integralność dokumentu ze sztuką, której dotyczy, również zostaje potwierdzona w Teatrze Witkacego. Tendencja do łączenia wydawnictwa ze spektaklem pojawiła się w nim już bardzo dawno. Widoczna staje się szczególnie w momencie analizy warstwy graficznej.

Każde wydawnictwo wiąże się z ogromnym wysiłkiem twórczym osób odpowiedzialnych za jego powstanie, a więc od strony graficznej 
Elżbiety Wernio i Ewy Dyakowskiej-Berbeki, zaś od strony literackiej Iwony Pawłowskiej, Iwony Romanówny, Teresy Sabo, Marzeny Garbowskiej i Agaty Balcerowskiej-Całki. Wysiłek tym większy, że doprowadza do wpisania publikacji TW w dwa kręgi. Z jednej strony jest to krąg dokumentów życia społecznego, pozwalających odzwierciedlić społeczną rzeczywistość, z drugiej - krąg źródeł badanych w kontekście nauki o teatrze.

\section{Bibliografia}

Balcerowska-Całka Agata, Garbowska Marzena, Informator Teatru im. Stanisława I. Witkiewicza, Zakopane-Kraków 2008.

Bibliotekarstwo, pod. red. Zbigniewa Żmigrodzkiego, Warszawa 1998.

Bułhak Ewa, Poetyka programu teatralnego, „Didaskalia” 1996, nr 15, s. 68-69. Chełstowski Edward, Wybrane problemy dokumentacji życia społecznego w bibliotekach, [w:] Dokumenty życia społecznego w bibliotece. Materiały z ogólnokrajowej konferencji zorganizowanej przez Bibliotekę Zakładu Narodowego im. Ossolińskich we Wrocławiu w dniach 2-3 czerwca 1969 roku, pod red. Janusza Albina, Wrocław-Warszawa-Kraków 1970, s. 9-24.

Encyklopedia wiedzy o ksiażce, pod red. Aleksandra Birkenmajera, Wrocław 1971. Estreicher Karol, Bibliografia polska XIX stulecia, t. 3, Kraków 1862.

Firlej-Buzon Aneta, Dokumenty życia społecznego w teorii i praktyce bibliotekarskiej w Polsce, Warszawa 2002.

Firlej-Buzon Aneta, Druki ulotne i okolicznościowe jako źródła do badań dziejów i kultury Dolnego Śląska lat 1945-1956, Wrocław 2013.

Frankowska Bożena, Encyklopedia teatru polskiego, Warszawa 2003.

Głombiowski Karol, Ksiqż̇ka w procesie komunikacji społecznej, Wrocław 1980. Jadzińska Monika, Rola dokumentacji w procesie zachowania i konserwacji sztuki współczesnej, „Sztuka i Dokumentacja” 2011, nr 4, s. 71-79.

Kiełkowski Lucjan, $O$ potrzebie gromadzenia materiałów dotyczacych środowisk artystycznych, [w:] Dokumenty życia społecznego w bibliotece. Materiały z ogólnokrajowej konferencji zorganizowanej przez Bibliotekę Zakładu Narodowego im. Ossolińskich we Wrocławiu w dniach 2-3 czerwca 1969 roku, pod red. Janusza Albina, Wrocław-Warszawa-Kraków 1970, s. 55-58.

Maj Witold, O programach teatralnych, „Almanach sceny polskiej” 1979, nr 19, s. $14-23$. 
Orzechowski Emil, Życie teatralne w świetle towarzyszących mu druków okolicznościowych, [w:] Druki ulotne i okolicznościowe - wartości i funkcje. Materiały międzynarodowej konferencji naukowej, pod red. Krzysztofa Migonia, Marty Skalskiej-Zlat, Anny Żbikowskiej-Migoń, Wrocław 2006, s. 279-296. Raszewski Zbigniew, Bilet do teatru. Szkice, Kraków 1998.

Rickards Maurice, The Encyclopedia of Ephemera. A guide to the fragmentary documents of everyday life for the collector, curator, and historian, ed. by Michael Twyman, Sally de Beaumont, Amoret Tanner, London 2001.

Słomianowska-Kamińska Emilia, Dokumenty życia społecznego $w$ bibliotekach akademickich - niektóre dylematy, „Toruńskie Studia Bibliologiczne” 2010, nr 2 (5), s. 147-156.

Sztabińska Paulina, Dokumentacja, ślad i kreacja artystyczna, „Sztuka i Dokumentacja" 2014, nr 10, s. 75-82.

Świąder Bożena, W metafizycznej dziurze. Teatr Witkacego w Zakopanem, Gdańsk 2002.

Wojciechowski Jacek, Podstawy pracy z czytelnikiem, Warszawa 1991.

Wojciechowski Jacek, Praca z użytkownikiem w bibliotece, Warszawa 2000.

\section{The programmes of Witkacy's Theatre in perspective of bibliology}

ABSTRACT: The article presents research on documents which were published by Witkacy's Theatre from 1985 to 2010. The content and publication form of the programmes were analysed. The article includes a presentation of selected documents and the state of research. The text also contains library context which was used as a starting point for next considerations.

KEYWORDS: bibliology, documents of social life, programmes, theatrical documents. 